\title{
Synthesis of nanostructured pirochromite magnesium chromate with egg shell membrane template
}

\author{
Tholkappiyan Ramachandran ${ }^{1}$ - Fathalla Hamed ${ }^{1}$
}

Received: 6 June 2016/Accepted: 3 August 2016/Published online: 11 August 2016

(c) The Author(s) 2016. This article is published with open access at Springerlink.com

\begin{abstract}
In this work, we report on the use of fresh and boiled egg shell membrane as bio-templates in the coprecipitation of pirochromite. The structure evolution, microstructure and optical properties of the ESM templated $\mathrm{MgCr}_{2} \mathrm{O}_{4}$ nanomaterial were studied by X-ray diffraction, Fourier transform infrared spectroscopy, scanning electron microscopy, Energy dispersive X-ray spectroscopy, elemental mapping and UV-Vis-NIR spectrophotometry. The annealing of the untemplated and templated co-precipitated $\mathrm{MgCr}_{2} \mathrm{O}_{4}$ powders at $1000{ }^{\circ} \mathrm{C}$ for $4 \mathrm{~h}$ produced single phased nanostructured material with spinel cubic crystal structure. The FTIR results showed slight variations in the band positions $v_{1}$ and $v_{2}$ which are attributed to the change in the microstructure due to the introduction of ESM in the preparation of $\mathrm{MgCr}_{2} \mathrm{O}_{4}$. The morphologies and average crystallite size of the annealed $\mathrm{MgCr}_{2} \mathrm{O}_{4}$ nanocrystalline powders depended on the type of the template. 3D hierarchical flake-like and mesh like structures were observed. The annealed $\mathrm{MgCr}_{2} \mathrm{O}_{4}$ nanocrystalline powders have shown excitonic absorptions in the visible range $300-500 \mathrm{~nm}$ due to the transitions that took place from the O- $2 p$ level to the $\mathrm{Cr}-3 d$ level. The optical band gap energies were found to be 3.68-3.71 eV for the direct band gap and 3.30-3.37 eV for the indirect band gap. This could make these $\mathrm{MgCr}_{2} \mathrm{O}_{4}$ nanocrystalline powders possible photocatalysts in the visible range $300-500 \mathrm{~nm}$.
\end{abstract}

Fathalla Hamed

fhamed@uaeu.ac.ae

1 Department of Physics, College of Science, United Arab Emirates University, Al Ain-15551, Abu Dhabi, United Arab Emirates
Keywords Pirochromite - Magnesium chromate · X-ray diffraction · Vibrational · Optical

\section{Introduction}

Spinel structures with the general chemical formula $\mathrm{AB}_{2} \mathrm{O}_{4}$, where $\mathrm{A}$, and $\mathrm{B}$ are two metal cations that occupy either the tetrahedral or the octahedral sites have made an impact on material science and technology. Depending on site occupancy, spinels are classified into three major types: normal, inverse, and random. Pirochromite $\mathrm{MgCr}_{2} \mathrm{O}_{4}$ is classified as normal spinel with cubic crystal structure where $\mathrm{Mg}$ and $\mathrm{Cr}$ ions occupy the tetrahedral and octahedral sites; it belongs to the space group ( $\mathrm{Fd} 3 \mathrm{~m})$, with 56 atoms per unit cell (O'Neill and Dollase 1994). $\mathrm{MgCr}_{2} \mathrm{O}_{4}$ has attracted the attention of many researchers because it could be utilized in applications such as interconnection material for solid oxide fuel cells (Schoonman et al. 1991), high temperature ceramics (Kim et al. 2001), humidity sensor elements (Drazic and Trontelj 1989), catalystssupport (Andrade et al. 2006), strengthening agents (Hashimoto and Yamagushi 1995) and combustion catalysts (Finocchio et al. 1995). In addition, $\mathrm{MgCr}_{2} \mathrm{O}_{4}$ refractories are important to the steel, cement, and copper industries (Deng et al. 2008; Ghosh et al. 2007). Recently, $\mathrm{MgCr}_{2} \mathrm{O}_{4}$ is used as an efficient complete combustant in the oxidation of propane and propene (Finocchio et al. 1994). The development of a synthesis route capable of producing $\mathrm{MgCr}_{2} \mathrm{O}_{4}$ nanomaterials with controlled size and morphology is important due to their potential applications as smart and functional materials. Various methods, such as solid state reaction (Finocchio et al. 1995), sol-gel method (SG) (Andrade et al. 2006), co-precipitation (Zhang et al. 1987), solution combustion (Arai et al. 1986), co- 
precipitation within reverse micro-emulsion (Rida et al. 2010), combustion method (Hosterman et al. 2013) and conventional double sintering ceramic technique (Khalaf et al. 2016) have been applied in the preparation of pirochromite based nanoparticles. Nevertheless, some of these methods are generally complicated, non-reliable, timeconsuming, and expensive for large scale production. To overcome these limitations, a lot of efforts have been directed towards exploring facile, flexible, reliable and cost effective methods for the preparation of pirochromite based nanomaterials either by adding reducing agents or green synthesis. Among the possible alternative synthesis methods, co-precipitation synthesis is particularly attractive due to its low cost, it seems to produce a mixed oxide and it allows some degree of control on size, morphology, composition, homogeneity and surface area (Hashimoto and Yamagushi 1995). The reducing agents play a fundamental role in the precipitation of the mixed oxide. Here, sodium hydroxide $(\mathrm{NaOH})$ was used as a reducing agent because it reacts non-violently in addition to being cheap and good complexant for metal cations.

Recently, template assisted nanomaterials have attracted an increasing interest because of their specific size and morphology (Balaz 2014; Oliveira et al. 2013). Compared with artificial templates, biological templates are inherently complex and hierarchical due to their fascinating structure which results in unique properties (Mann 2001). Moreover, they are generally inexpensive, abundant, and environmentally benign (Mann 2000). Biological template like eggshell membrane (ESM) has been used to synthesize the spinel nanomaterials with controlled size and hierarchically ordered microporous structures. It is widely studied because of its remarkable properties, which could be utilized in catalysis, adsorption of heavy metals $[\mathrm{Au}(\mathrm{I})$ and $\mathrm{Au}(\mathrm{III})$ ] (Ishikawa et al. 2002), dyes (malachite green) (Chen et al. 2012) and organics (eosin B) (Ning and Tao 2011), biosensors (immobilized enzyme glucose oxidase) (Zheng et al. 2011), sulfonates (Wang et al. 2010) and fluorides (Lunge et al. 2012). In addition, EMS has been also used in medical industries as a possible new effective and safe therapeutic option for the treatment of pain and inflexibility associated with joint and connective tissue (JCT) disorders (Ruff et al. 2009). ESM has found applications in ophthalmology as a cheap and versatile eye model which could be used during vitreous surgery training (Benson et al. 2012). Moreover; ESM was found to represent an interesting biomaterial for electrochemical application such as a separator in supercapacitors (Li et al. 2012).

We report herein on a novel biotemplate method using ESM, environmentally friendly and natural biomembrane for preparing pirochromite $\mathrm{MgCr}_{2} \mathrm{O}_{4}$ nanostructured materials. ESM is constituted of three layers in the egg shell (ES): (1) outer layer, (2) inner layer and (3) limiting membrane layer. The inner ESM and limiting membrane layer can be easily pealed; however, the outer ESM is strongly bonded into the calcite $\left(\mathrm{CaCO}_{3}\right)$ which is the major component in ES. To separate the outer ESM layer from the ES, a general acidic treatment has been used by various researchers such as (1) dissolving the ES in acid medium (e.g., dilute acetic acid, $\mathrm{HCl}$ ), (2) immersing the ES in acid medium which does not completely dissolve the ES, but it will allow the separation of the ESM, (3) dissolved air flotation separation unit and (4) simply stripping the outer ESM from the ES. To the best of our knowledge, using ESM in the preparation of spinel type $\mathrm{MgCr}_{2} \mathrm{O}_{4}$ by co-precipitation is not available yet. In this research article, we report a novel biomorphic technique to obtain self-supported $\mathrm{MgCr}_{2} \mathrm{O}_{4}$ fibrous networks of nanocrystallites with high surface area using egg shell membrane (ESM) as templates. Co-precipitated templated $\mathrm{MgCr}_{2} \mathrm{O}_{4}$ on boiled or fresh ESM were prepared. The structural, morphological and optical properties of the ESM templated $\mathrm{MgCr}_{2} \mathrm{O}_{4}$ samples were characterized by X-ray diffractometry (XRD), Fourier transfer infrared spectroscopy (FTIR), Scanning electron microscopy (SEM), Energy dispersive X-ray spectrometry (EDS), and UV-Vis-NIR spectrophotometry.

\section{Experimental}

\section{Materials}

Reagent grades of chemicals were used from all chemical sources; such as magnesium nitrate hexahydrate $\left(\mathrm{MgN}_{2}\right.$ $\mathrm{O}_{6} \cdot 6 \mathrm{H}_{2} \mathrm{O}, \geq 98 \%$ purity, Sigma-Aldrich), chromium (III) nitrate nonahydrate $\left(\mathrm{CrN}_{3} \mathrm{O}_{9} \cdot 9 \mathrm{H}_{2} \mathrm{O}, 99 \%\right.$ purity, SigmaAldrich). Sodium hydroxide pellets purify LR $(\mathrm{NaOH}$, $97 \%$ purity, SDFCL fine chem limited).

\section{Characterizations}

The X-ray diffraction patterns were recorded by SHIMADZU Lab X-XRD-6100 with $\mathrm{CuK} \alpha(\lambda=1.5418 \AA)$ line at scanning rate of $0.02 \% \mathrm{~min}$. FTIR measurements were performed in VARIAN 3100 FTIR, Excalibur series spectrophotometer. Small amounts of the powders were mixed with potassium bromide $(\mathrm{KBr})$ and pressed into $1 \mathrm{~mm}$ thick discs. FTIR spectra were collected from these discs over the range $400-2300 \mathrm{~cm}^{-1}$ at room temperature. SEM studies were performed in JEOL JSM-6010LA operated at $20 \mathrm{keV}$ accelerating voltage. SEM images were obtained in the secondary electron imaging (SEI) mode. Elemental composition and mapping were obtained from the analyses of EDS. The optical absorption spectra were measured by Jasco V-670 spectrophotometer over a UV- 
Vis-NIR region in the diffuse reflectance mode. Small amounts $\sim 1 \mathrm{mg}$ of sample powders were completely dissolved into $5 \mathrm{ml}$ of ethanol to form transparent solutions. UV-Vis-NIR spectra were collected from these solutions. The light sources used are a deuterium (D2) lamp for the UV region and a halogen (WI) lamp for the VIS/NIR region.

\section{Co-precipitation of $\mathrm{MgCr}_{2} \mathrm{O}_{4}$ nanocrystalline powders}

Magnesium chromate nanocrystalline powders with the chemical formula of $\mathrm{MgCr}_{2} \mathrm{O}_{4}$ were prepared by co-precipitation technique. The starting metal nitrates were weighted in accordance with the desired nominal stoichiometric ratio and dissolved into $20 \mathrm{ml}$ of de-ionized water. To get complete mixing of the solvents, the solution was stirred for 30 minutes using magnetic stirrer. Then, few grams of sodium hydroxide $(\mathrm{NaOH})$ were added dropwise into the metal nitrates solution. The aqueous solution was maintained at a $\mathrm{pH}$ level $=12$ while stirring for 4 hours at a temperature of $60{ }^{\circ} \mathrm{C}$. Then the mixed solution was aged for 5 hours at room temperature. The aged solution was placed in the ultrasonic water bath (XUB5 series-Grant scientific instruments LTD, UK). Then, the solution was sonicated for 1.5 hours at a power of $5 \mathrm{~W} / \mathrm{cm}^{2}$. The obtained precipitates were washed with de-ionized water and acetone several times, dried in vacuum at $100{ }^{\circ} \mathrm{C}$ for 8 hours to remove the water content. The resulted dried powder was ground using an agate mortar and pestle to a fine powder. The obtained fine powder was subjected to heat treatment at $1000{ }^{\circ} \mathrm{C}$ for 4 hours in ambient atmosphere. All experiments were carried out in ambient conditions under atmosphere. The schematic diagram represents the synthesized magnesium chromate nanocrystalline powders are shown in Fig. 1.

\section{Separation of fresh egg-shell membrane from egg- shell}

Fresh eggs were purchased from a local super market. They were gently washed with tap water to remove any albumen from the egg shell membrane, and then rinsed with deionized water. The eggs were carefully broken at the blunt end, yolk and white contents were manually removed. Then, the eggshells were repeatedly washed with de-ionized water. Using tweezers, the inner shell membrane and the limiting membrane were removed carefully and dipped in $10 \mathrm{ml}$ hydrochloric acid to dissolve any $\mathrm{CaCO}_{3}$ from the shell membrane. The obtained EMS was then washed in de-ionized water for three times and kept in an oven at $60{ }^{\circ} \mathrm{C}$ to remove any water content. The resulting dried membranes were used as the template for the synthesis of magnesium chromate materials. Figure 1 shows an SEM image of an egg-shell membrane. It shows the unique intricate microstructures with porous morphologies.
Fig. 1 Schematic diagram of co-precipitation of boiled eggshell membrane templated and fresh egg-shell membrane templated of $\mathrm{MgCr}_{2} \mathrm{O}_{4}$ nanocrystalline powders

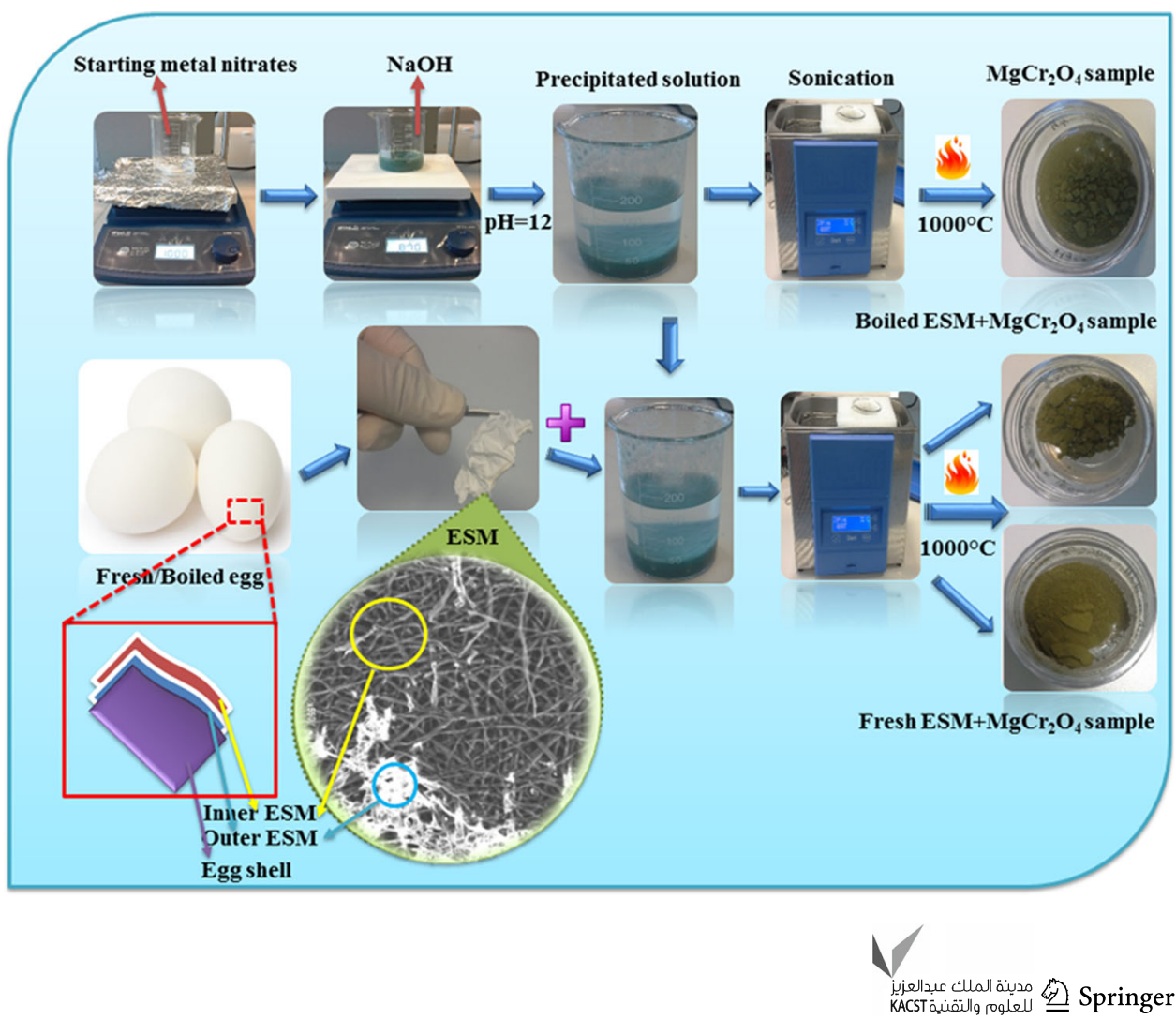


Fig. 2 a XRD pattern of fresh ESM, b SEM images of fresh ESM sample: the inner layer is on left and the outer layer is on right, c EDS spectra for fresh ESM, d magnified image of the inner layer of ESM
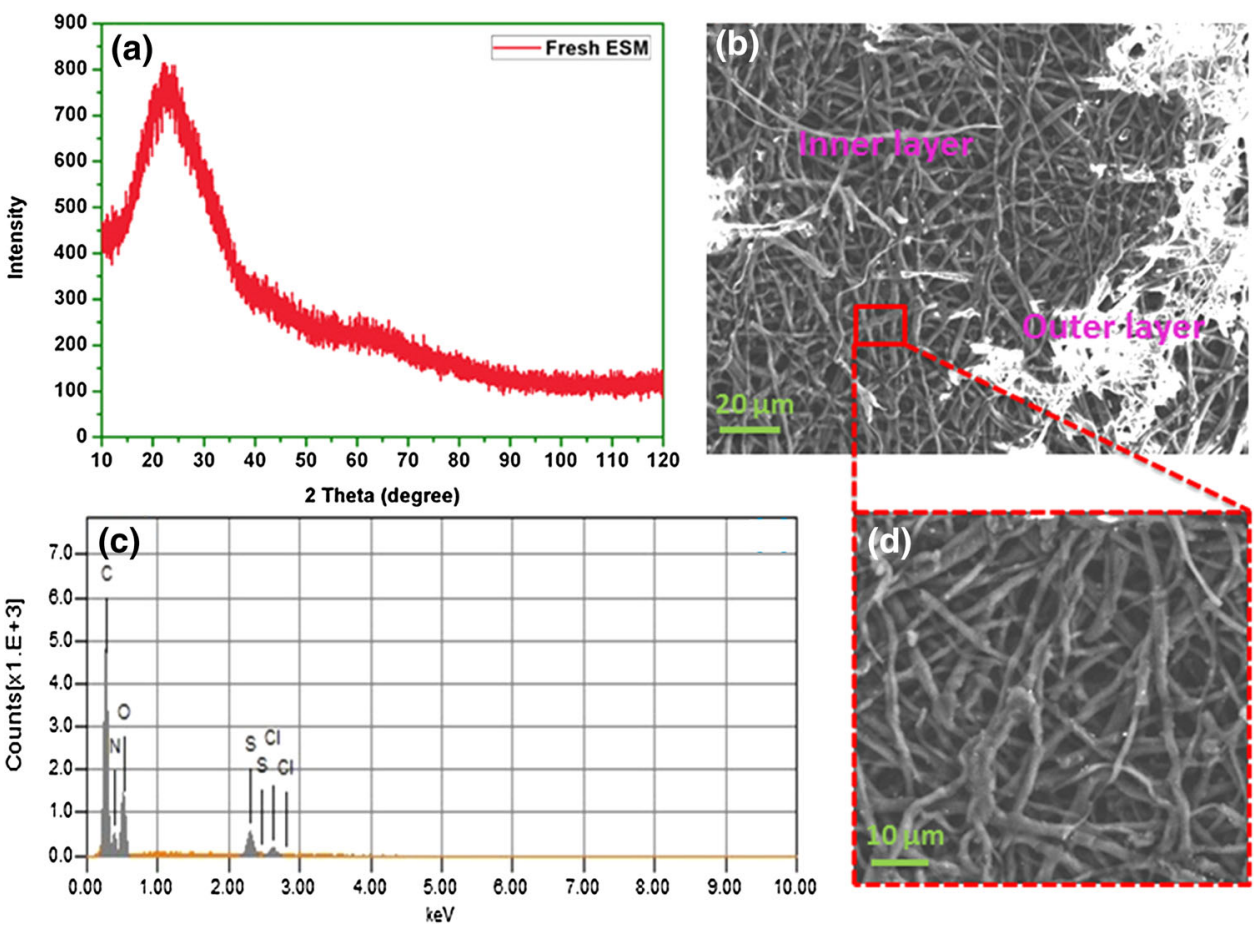

Fabrication of egg-shell membrane templated $\mathrm{MgCr}_{2} \mathrm{O}_{4}$ nanocrystalline powder

In a typical process, the egg-shell membranes were dispersed in $25 \mathrm{ml}$ de-ionized water and subsequently mixed with $40 \mathrm{ml}$ of co-precipitated precursor solution ("Coprecipitation of $\mathrm{MgCr}_{2} \mathrm{O}_{4}$ nanocrystalline powders") under vigorous magnetic stirring for 4 hours. To obtain a homogeneous solution, the mixed solution was then sonicated for 1.5 hours at room temperature. The resulted product was washed with de-ionized water and acetone six times. It was then dried in vacuum at $100{ }^{\circ} \mathrm{C}$ for 8 hours to remove any water content. The resultant dried product was ground by hand with a pestle in an agate mortar to a fine powder. The obtained fine powder was subjected to heat treatment at $1000{ }^{\circ} \mathrm{C}$ for 4 hours in ambient atmosphere, then it was allowed to cool down to room temperature. A schematic representation of the formation of $\mathrm{MgCr}_{2} \mathrm{O}_{4}$ / egg-shell membrane composite is illustrated in Fig. 1.

\section{Results and discussion}

\section{Fresh ESM studies}

The XRD pattern of a fresh ESM sample is shown in Fig. 2a. The figure clearly shows the amorphous structure of the fresh ESM with a broad peak around $20^{\circ}-30^{\circ}$. The morphology of this ESM was examined by SEM as shown in Fig. 2b. The fresh ESM is a double layer membrane, the outer layer of the ESM which on the right side on the SEM image and the inner layer of ESM which is on the left side of the SEM image. These membrane layers appeared to be porous fiber like network, composed of interlaced proteins. In comparison to the outer layer, the inner layer has spatial voids and branches in the fibrous network as shown in Fig. 2d. It appears to be more uniform with finer structure. The individual fibers have an average diameter of $\sim 1 \mu \mathrm{m}$; however, they are randomly oriented.

The elemental analysis of fresh ESM was determined from EDS. Figure 2c shows the EDS spectra for the freshly prepared ESM. The analysis of these EDS spectra indicates that the presence of $\mathrm{C}, \mathrm{N}, \mathrm{O}, \mathrm{S}$ and $\mathrm{Cl}$. No other foreign elements such as $\mathrm{Ca}, \mathrm{Mg}$ and $\mathrm{P}$ were detected in the fresh ESM. Usually these foreign elements/species are present in the calcium based egg shell. This confirms the complete removal of the egg shell membrane from the egg shell. Figure $3 \mathrm{a}-\mathrm{f}$ shows the elemental mapping and distribution of $\mathrm{C}, \mathrm{N}, \mathrm{O}, \mathrm{S}$, and $\mathrm{Cl}$ within the fresh ESM sample. Different colors are subjected to the diverse emission lines where each color in the EDS mapping refers to the single emission line of $\mathrm{C}, \mathrm{N}, \mathrm{O}, \mathrm{S}$ and $\mathrm{Cl}$ elements. It can be seen that the $\mathrm{C}, \mathrm{N}$, $\mathrm{O}, \mathrm{S}$, and $\mathrm{Cl}$ are generally well distributed and uniform. The analysis of EDS mapping indicates that these elements are incorporated within the entire fresh ESM.

\section{Boiled ESM studies}

Figure $4 \mathrm{a}$ shows the SEM image of the boiled ESM. It shows that the spatial voids and branches in the fibrous 
Fig. 3 a SEM micrograph and b-f EDS mapping of C, N, O, S and $\mathrm{Cl}$ for fresh ESM sample
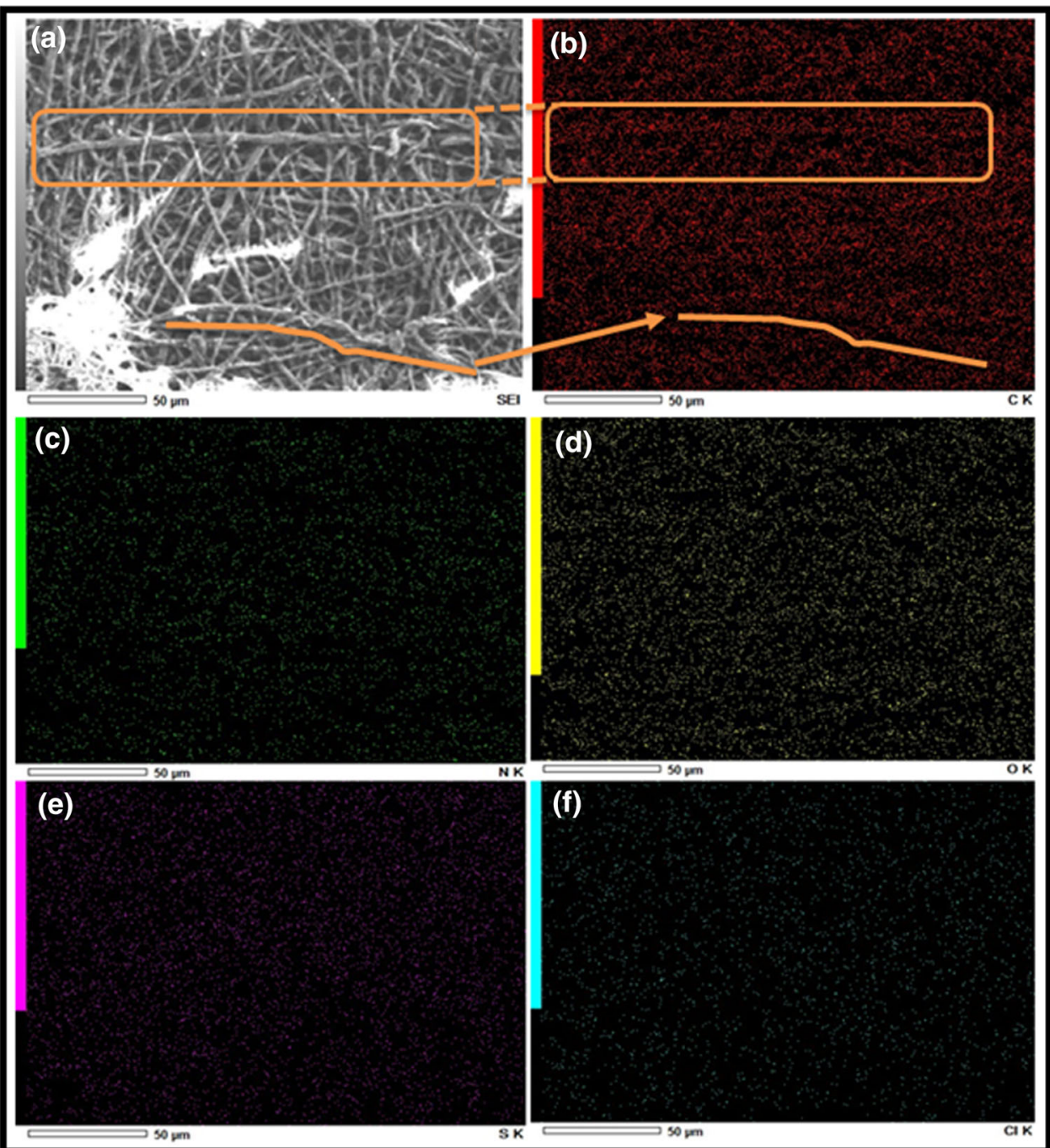

network had undergone shrinkage. Figure $4 \mathrm{~b}$ shows that the fibrous network in the boiled ESM had become collapsed and coarsened into lumps that vary between 30 and $40 \mu \mathrm{m}$ in size. Trace amount of non-volatile elements such as $\mathrm{S}$ and $\mathrm{Cl}$ were completely removed and only $\mathrm{C}, \mathrm{N}$, and $\mathrm{O}$ were detected in these lumps as shown in Fig. 4c.

\section{X-ray diffraction (XRD) studies}

The crystal structure of the prepared $\mathrm{MgCr}_{2} \mathrm{O}_{4}$ nanocrystalline powders was examined by X-ray diffractometer. Figure 5a shows the powder X-ray diffraction (XRD) pattern of the co-precipitated $\mathrm{MgCr}_{2} \mathrm{O}_{4}$ nanocrystalline powder annealed at $800{ }^{\circ} \mathrm{C}$ for 4 hours. The figure shows all the diffraction peaks (111), (220), (311), (222), (400), (331), (422), (511), (440), (531), (620), (533), (622), (441), (551), (642), (731), (800), (751), (840), and (911) that correspond to the normal spinel-cubic structure of magnesium chromate. These peaks were well matched with JCPDS card no. 10-0351 for $F d-3 m$ space symmetric group. No additional secondary diffraction peaks were detected in the XRD pattern, which indicates the formation of single phase $\mathrm{MgCr}_{2} \mathrm{O}_{4}$ nanocrystalline powders. Figure 6 a shows the XRD pattern of the as-synthesized boiled egg shell membrane templated $\mathrm{MgCr}_{2} \mathrm{O}_{4}$ sample. It shows a very broad peak near $20^{\circ}-40^{\circ}$, and the same thing is observed for fresh egg shell membrane templated $\mathrm{MgCr}_{2} \mathrm{O}_{4}$ sample as shown in Fig. 7a with the exception to a very weak peak near $29.3^{\circ}$. This peak might be due to the presence of minute traces of $\mathrm{CaCO}_{3}$ left over from the process of dissolving the egg shell. The co-precipitated boiled and fresh ESM templated $\mathrm{MgCr}_{2} \mathrm{O}_{4}$ has shown an amorphous nature, to bring out the spinel phase of $\mathrm{MgCr}_{2} \mathrm{O}_{4}$ further calcination is needed. Similar heat treatments had to be carried out in the preparation of $\mathrm{MgCr}_{2} \mathrm{O}_{4}$ by sol-gel method (Tripathi and Nagarajan 2016). 
Fig. 4 a SEM image,

b magnified image and c EDS spectra for boiled ESM sample
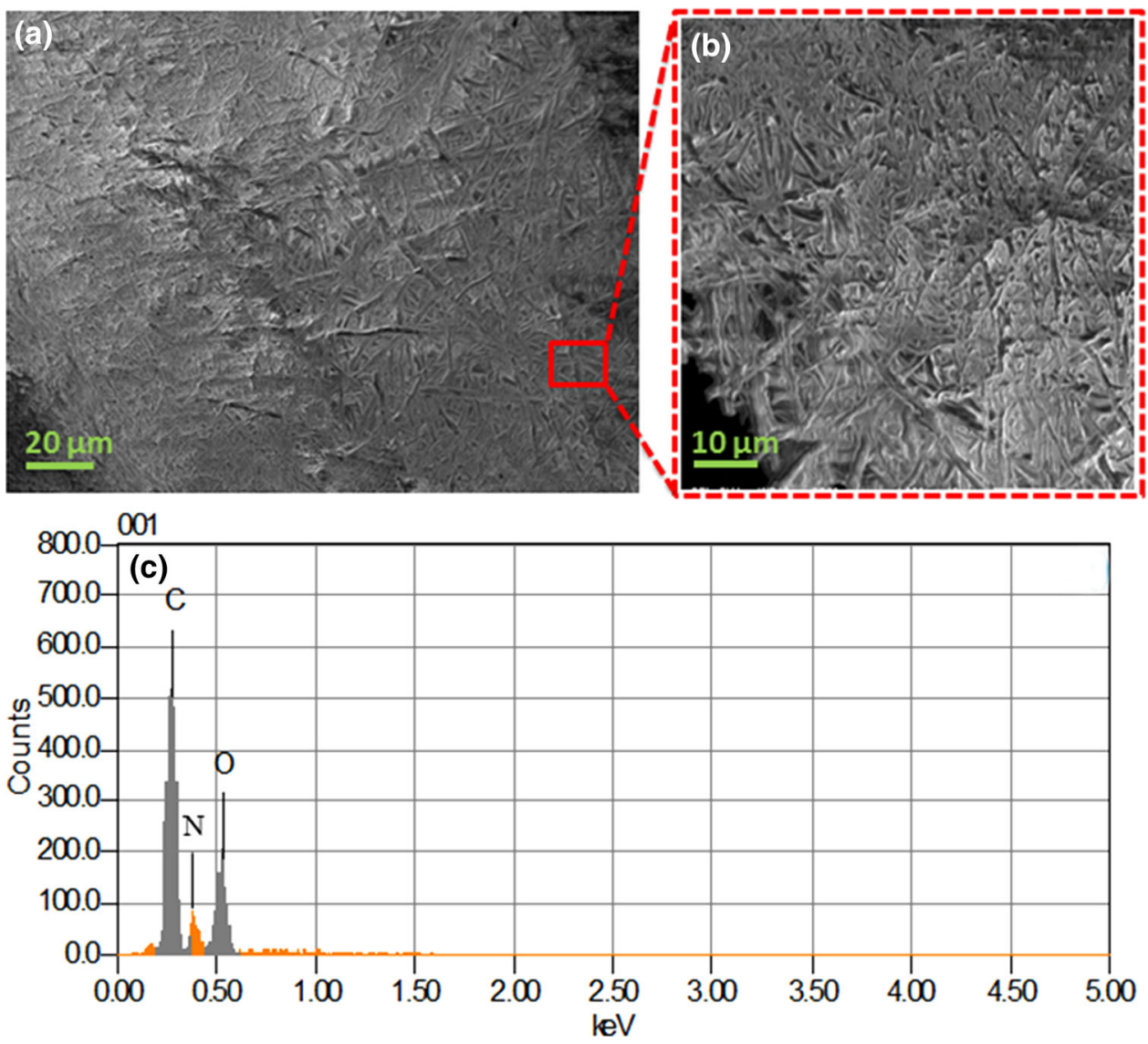

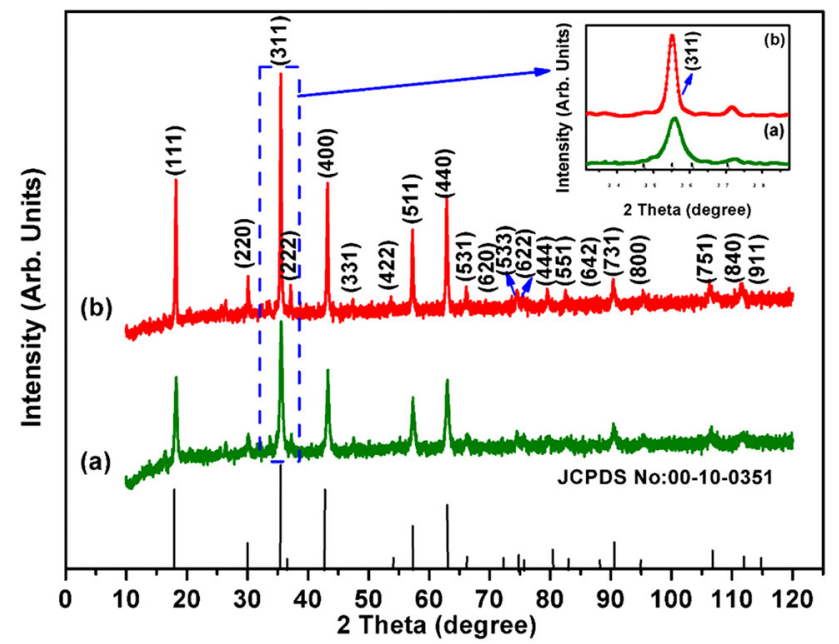

Fig. 5 X-ray diffraction (XRD) pattern of co-precipitated un-templated $\mathrm{MgCr}_{2} \mathrm{O}_{4}$ nanocrystalline powder annealed for $4 \mathrm{~h}$ a a at $800{ }^{\circ} \mathrm{C}$ and $\mathbf{b}$ at $1000{ }^{\circ} \mathrm{C}$

\section{Heat treatments}

To investigate the effect of annealing on the crystal structure of the co-precipitated $\mathrm{MgCr}_{2} \mathrm{O}_{4}$ nanocrystalline powders, samples of co-precipitated powders were annealed at $1000{ }^{\circ} \mathrm{C}$ for 4 hours. Figure $5 b$ shows the XRD

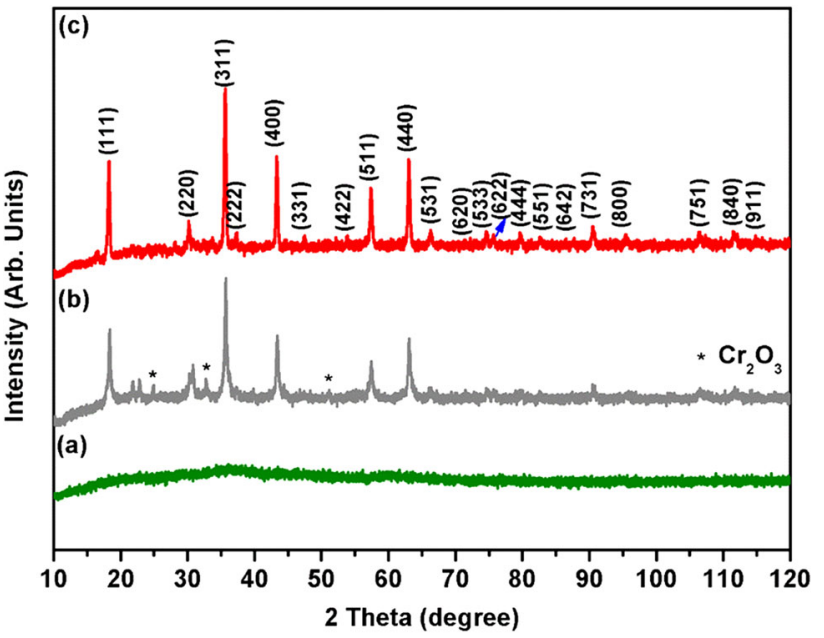

Fig. 6 X-ray diffraction (XRD) pattern of co-precipitated boiled ESM templated $\mathrm{MgCr}_{2} \mathrm{O}_{4}$ nanocrystalline powder a as co-precipitated, $\mathbf{b}$ annealed at $800{ }^{\circ} \mathrm{C}$ for $4 \mathrm{~h}$ and $\mathbf{c}$ annealed at $1000{ }^{\circ} \mathrm{C}$ for $4 \mathrm{~h}$. Asterisk marks indicate peaks attributed to $\mathrm{Cr}_{2} \mathrm{O}_{3}$ phase

patterns (top curve) for the $1000{ }^{\circ} \mathrm{C}$ annealed $\mathrm{MgCr}_{2} \mathrm{O}_{4}$ sample, all the diffraction peaks match those of the $800{ }^{\circ} \mathrm{C}$ annealed sample. The peaks match very well to the crystal structure of $\mathrm{MgCr}_{2} \mathrm{O}_{4}$ in accordance with JCPDS card no. 00-010-0351. In comparison to the $800{ }^{\circ} \mathrm{C}$ annealed 


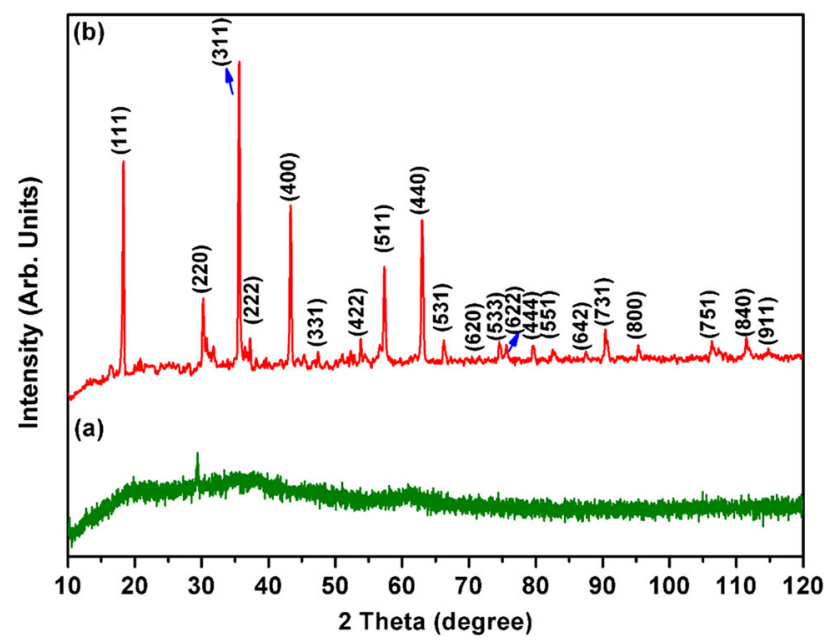

Fig. 7 X-ray diffraction (XRD) pattern of co-precipitated fresh ESM templated $\mathrm{MgCr}_{2} \mathrm{O}_{4}$ nanocrystalline powders a as co-precipitated and b annealed at $1000{ }^{\circ} \mathrm{C}$ for $4 \mathrm{~h}$

$\mathrm{MgCr}_{2} \mathrm{O}_{4}$ nanocrystalline sample, the diffraction peaks of the $1000{ }^{\circ} \mathrm{C}$ annealed $\mathrm{MgCr}_{2} \mathrm{O}_{4}$ sample are more intense with less broadening as shown in the inset of Fig. 5. The higher the annealing temperature the greater the degree of crystallinity. The average crystallite size $(t)$ of the annealed co-precipitated $\mathrm{MgCr}_{2} \mathrm{O}_{4}$ nanocrystalline powders was calculated from the Scherrer formulism in accordance with the following equation (Hamed et al. 2016),

$t=k \lambda /(\beta \cos \theta)$,

where $k$ is a constant and it is equal to $0.9, \lambda$ is the $\mathrm{CuK}_{\alpha}$ $\mathrm{X}$-ray line at $1.5405 \AA$, $\beta$ is the full width at half maximum after instrumental broadening correction, and $\theta$ is the diffraction angle. The calculated values of average crystallite size $(t)$ were found to be 30.8 and $63.2 \mathrm{~nm}$ for the 800 and $1000{ }^{\circ} \mathrm{C}$ annealed samples, respectively, these values are listed in Table 1 . In comparison, these values are within range of the reported values of $28.7 \mathrm{~nm}$ for particles prepared by conventional solid phase reaction (Khalaf et al. 2016), $30.2 \mathrm{~nm}$ by sol-gel method (He 2010) and 52.4 and $6.4 \mathrm{~nm}$ by sol-gel and co-precipitation with reverse microemulsion (Rida et al. 2010).

Figure 6band $\mathrm{c}$ is a presentation of the powder X-ray diffraction profiles for the annealed boiled ESM templated
$\mathrm{MgCr}_{2} \mathrm{O}_{4}$ nanocrystalline powders. The diffraction peaks of the $800{ }^{\circ} \mathrm{C}$ annealed sample do not match well with the crystal structure of $\mathrm{MgCr}_{2} \mathrm{O}_{4}$ (JCPDS card no. 00-0100351). The additional peaks could be attributed to the presence of segregated secondary $\mathrm{Cr}_{2} \mathrm{O}_{3}$ phase. However, the diffraction peaks of the $1000{ }^{\circ} \mathrm{C}$ annealed sample match well with those of the normal spinel-cubic crystal structure of $\mathrm{MgCr}_{2} \mathrm{O}_{4}$ (JCPDS 00-010-0351). Therefore, the possible existence of a secondary $\left(\mathrm{Cr}_{2} \mathrm{O}_{3}\right)$ phase in the $1000{ }^{\circ} \mathrm{C}$ annealed sample is excluded. The average crystallite size $(t)$ of the $1000{ }^{\circ} \mathrm{C}$ annealed boiled ESM templated $\mathrm{MgCr}_{2} \mathrm{O}_{4}$ nanocrystalline powder was estimated to $46.9 \mathrm{~nm}$, this is $25 \%$ less than the $1000{ }^{\circ} \mathrm{C}$ annealed untemplated $\mathrm{MgCr}_{2} \mathrm{O}_{4}$ nanocrystalline powder. The powder $\mathrm{X}$-ray diffraction pattern of the $1000{ }^{\circ} \mathrm{C}$ annealed fresh ESM templated $\mathrm{MgCr}_{2} \mathrm{O}_{4}$ nanocrystalline powder is shown in Fig. 7b. The diffraction peaks in the pattern can be indexed with the normal spinel-cubic crystal structure of $\mathrm{MgCr}_{2} \mathrm{O}_{4}$ (JCPDS no. 10-0351). The average crystallite size $(t)$ in the $1000{ }^{\circ} \mathrm{C}$ annealed fresh ESM templated $\mathrm{MgCr}_{2} \mathrm{O}_{4}$ nanocrystalline powder was calculated to be $64.5 \mathrm{~nm}$, this is approximately the same size as the one in the $1000{ }^{\circ} \mathrm{C}$ annealed un-templated $\mathrm{MgCr}_{2} \mathrm{O}_{4}$ nanocrystalline powder.

The lattice constant $(a)$ of the $1000{ }^{\circ} \mathrm{C}$ annealed untemplated, boiled ESM templated and fresh ESM templated $\mathrm{MgCr}_{2} \mathrm{O}_{4}$ nanocrystalline powders were calculated using the following relation (Hamed et al. 2016).

$\frac{\lambda \sqrt{h^{2}+k^{2}+l^{2}}}{2 \sin \theta}=a$,

where $\lambda$ is the X-ray wave length $\left(1.5405 \times 10^{-10} \mathrm{~m}\right)$, $(h k l)$ are the Miller indices and $\theta$ is the diffraction angle that corresponds an $(h k l)$ plane. The calculated values of lattice constants of the $1000{ }^{\circ} \mathrm{C}$ annealed un-templated, boiled ESM templated and fresh ESM templated $\mathrm{MgCr}_{2} \mathrm{O}_{4}$ nanocrystalline powders are 8.347, 8.323 and $8.324 \AA$, respectively as listed in Table 1 . In comparison, these values are in good agreement with the reported values of $8.333 \AA$ for $\mathrm{MgCr}_{2} \mathrm{O}_{4}$ (Stefanescua et al. 2011), $8.39 \AA$ for $\mathrm{MgFeCrO}_{4}$ (Hankare et al. 2009) and $8.381 \AA$ for $\mathrm{Mg}_{0.5-}$ $\mathrm{Zn}_{0.5} \mathrm{FeCrO}_{4}$ (Haralkar et al. 2012).

Table 1 Average crystallite size $(t) \mathrm{nm}, \mathrm{X}$-ray density $\left(d_{X}\right)$, surface area $\left(\mathrm{m}^{2} / \mathrm{g}\right)$, lattice constant $(a)(\AA)$ for the $1000{ }^{\circ} \mathrm{C}$ annealed co-precipitated un-templated, boiled ESM templated and fresh ESM templated $\mathrm{MgCr}_{2} \mathrm{O}_{4}$ nanocrystalline powders for $4 \mathrm{~h}$

\begin{tabular}{lllll}
\hline Samples annealed at $1000{ }^{\circ} \mathrm{C}$ for $4 \mathrm{~h}$ & Average crystallite size, $t(\mathrm{~nm})$ & $\begin{array}{l}\mathrm{X} \text {-ray density }\left(d_{X}\right) \\
\mathrm{g} / \mathrm{cm}^{3}\end{array}$ & Surface area $(S)\left(\mathrm{m}^{2} / \mathrm{g}\right)$ & Lattice constant $(a)(\AA)$ \\
\hline Un-templated $\mathrm{MgCr}_{2} \mathrm{O}_{4}$ & 63.2 & 4.39 & 21.59 & 8.347 \\
Boiled ESM templated $\mathrm{MgCr}_{2} \mathrm{O}_{4}$ & 46.9 & 4.42 & 28.84 & 8.323 \\
Fresh ESM templated $\mathrm{MgCr}_{2} \mathrm{O}_{4}$ & 64.5 & 4.43 & 21.0 & 8.324 \\
\hline
\end{tabular}


The X-ray density $\left(d_{X}\right)$ of the $1000{ }^{\circ} \mathrm{C}$ annealed untemplated, boiled ESM templated and fresh ESM templated $\mathrm{MgCr}_{2} \mathrm{O}_{4}$ nanocrystalline powders were determined from the following simple relation (Hamed et al. 2016).

$d_{X}=8 M / N_{A} V$,

where $M$ is the molecular weight of the sample, $V$ is the unit cell volume ( $V=a^{3}$ for cubic) and $N_{A}$ is the Avogadro's number $\left(N_{A}=6.023 \times 10^{23} / \mathrm{mol}\right)$. The calculated values of $d_{X}$ are $4.39,4.42$ and $4.43 \mathrm{~g} / \mathrm{cm}^{3}$ for the un-templated, boiled ESM templated and fresh ESM templated, respectively (Table 1). These values are almost the same and are in good agreement with the reported value of $4.43 \mathrm{~g} / \mathrm{cm}^{3}$ for $\mathrm{MgCr}_{2} \mathrm{O}_{4}$ prepared by co-crystallization method (Haralkar et al. 2012). The specific surface area $(S)$ of the $1000{ }^{\circ} \mathrm{C}$ annealed samples were calculated with the help of X-ray density $\left(d_{X}\right)$ and average crystallite size $(t)$ in accordance with the following expression (Hamed et al. 2016)

$S=6 / d_{X}(t)$.

The values of specific surface area of the $1000{ }^{\circ} \mathrm{C}$ annealed un-templated, boiled ESM templated and fresh ESM templated $\mathrm{MgCr}_{2} \mathrm{O}_{4}$ nanocrystalline powders were determined to be $21.59,28.84$ and $21.0 \mathrm{~m}^{2} / \mathrm{g}$, respectively. The $1000{ }^{\circ} \mathrm{C}$ annealed boiled ESM templated $\mathrm{MgCr}_{2} \mathrm{O}_{4}$ nanocrystalline powder has a surface area that $33 \%$ higher than the other two samples, this is due to its smaller average crystallite size.

\section{Fourier transfer infrared spectroscopy (FTIR) studies}

FTIR studies were conducted to shade some light on the position of the cations within the crystal structure of the $1000{ }^{\circ} \mathrm{C}$ annealed un-templated, boiled ESM templated and fresh ESM templated $\mathrm{MgCr}_{2} \mathrm{O}_{4}$ nanocrystalline powders. Figure 8 shows the recorded FTIR spectra at room temperature over the shorter wavelength range of $400-2300 \mathrm{~cm}^{-1}$. The strongest observed absorption bands are within this range $400-700 \mathrm{~cm}^{-1}$. These bands correspond to the intrinsic stretching vibrational bonds in the single-phase spinel structure with two sublattices: tetrahedral (A) sites and octahedral (B) sites (White and De Angelis 1967). The position and intensity of these bands depend on the nature of cations distribution and their occupancy in the sub-lattices of the spinel structure. For pirochromite, the absorption band $v_{1}$ observed around $\sim 631 \mathrm{~cm}^{-1}$ is attributed to the stretching vibrational mode between metal ions and oxygen ions in the tetrahedral sites; whereas the absorption band $v_{2}$ observed around $\sim 440 \mathrm{~cm}^{-1}$ is attributed to the stretching vibrational mode between metal ions and oxygen ions in the octahedral site. The difference between the band positions of $v_{1}$ and $v_{2}$ is

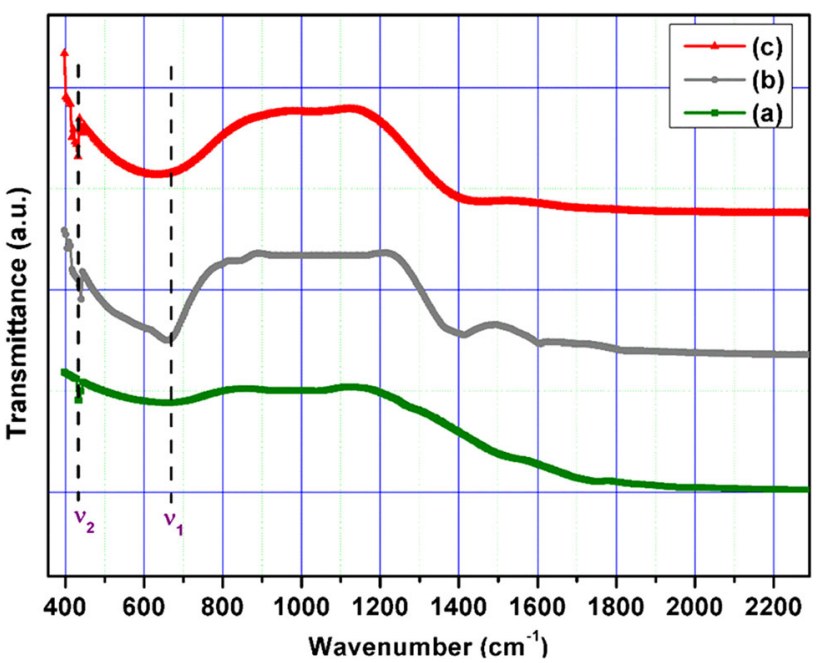

Fig. 8 FTIR spectrum of the $1000{ }^{\circ} \mathrm{C}$ annealed co-precipitated $\mathrm{MgCr}_{2} \mathrm{O}_{4}$ nanocrystalline powders for $4 \mathrm{~h}$ a un-templated, $\mathbf{b}$ boiled ESM templated and $\mathbf{c}$ fresh ESM templated

expected due to the difference in the $\mathrm{Fe}^{3+}-\mathrm{O}^{2-}$ bond lengths in the octahedral and the tetrahedral sites. Similar observations have been reported for various spinel systems (Morozova and Popov 2010; Bhosale and Chougule 2006; Zaki and Sc 2010). The $v_{1}$ and $v_{2}$ band positions in our samples are almost same, this makes us believe that we have the right cations distribution for the normal spinelcubic structure in our $\mathrm{MgCr}_{2} \mathrm{O}_{4}$ samples.

\section{Morphology and elemental analysis}

Here we present morphological and elemental mapping and compositional studies conducted on different co-precipitated $\mathrm{MgCr}_{2} \mathrm{O}_{4}$ samples. Figure 9a, c, d, e shows SEM images of the $1000{ }^{\circ} \mathrm{C}$ annealed un-templated $\mathrm{MgCr}_{2} \mathrm{O}_{4}$ sample. The images show the formation of nano-sized structures with irregular shapes. One can find that many nanorod-like shapes (Fig. 9c, d, e) are assembled to form isolated nanoflakes. These $\mathrm{MgCr}_{2} \mathrm{O}_{4}$ nanoflakes have sharp tip $(\sim 10 \mathrm{~nm})$, width $(\sim 190 \mathrm{~nm})$ and lengths that range from 430 to $500 \mathrm{~nm}$. The SEM image also show clusters of nanoparticles, aggregates and cube like shapes (highlighted by yellow color in Fig. 9a). The $1000{ }^{\circ} \mathrm{C}$ annealed untemplated $\mathrm{MgCr}_{2} \mathrm{O}_{4}$ sample is a mix of different nanostructured shapes. The elemental composition was determined from the analyses of energy dispersive X-ray (EDS) spectroscopy. Figure $9 \mathrm{~b}$ is an energy dispersive spectrum of the $1000{ }^{\circ} \mathrm{C}$ annealed un-templated $\mathrm{MgCr}_{2} \mathrm{O}_{4}$ sample. The spectrum shows the presence of $\mathrm{Mg}, \mathrm{Cr}$ and $\mathrm{O}$. No foreign elements or impurity were detected within the limits of our EDS detector. The elemental analysis of the EDS spectrum is in good agreement with the expected nominal chemical composition of $\mathrm{MgCr}_{2} \mathrm{O}_{4}$. The results of 

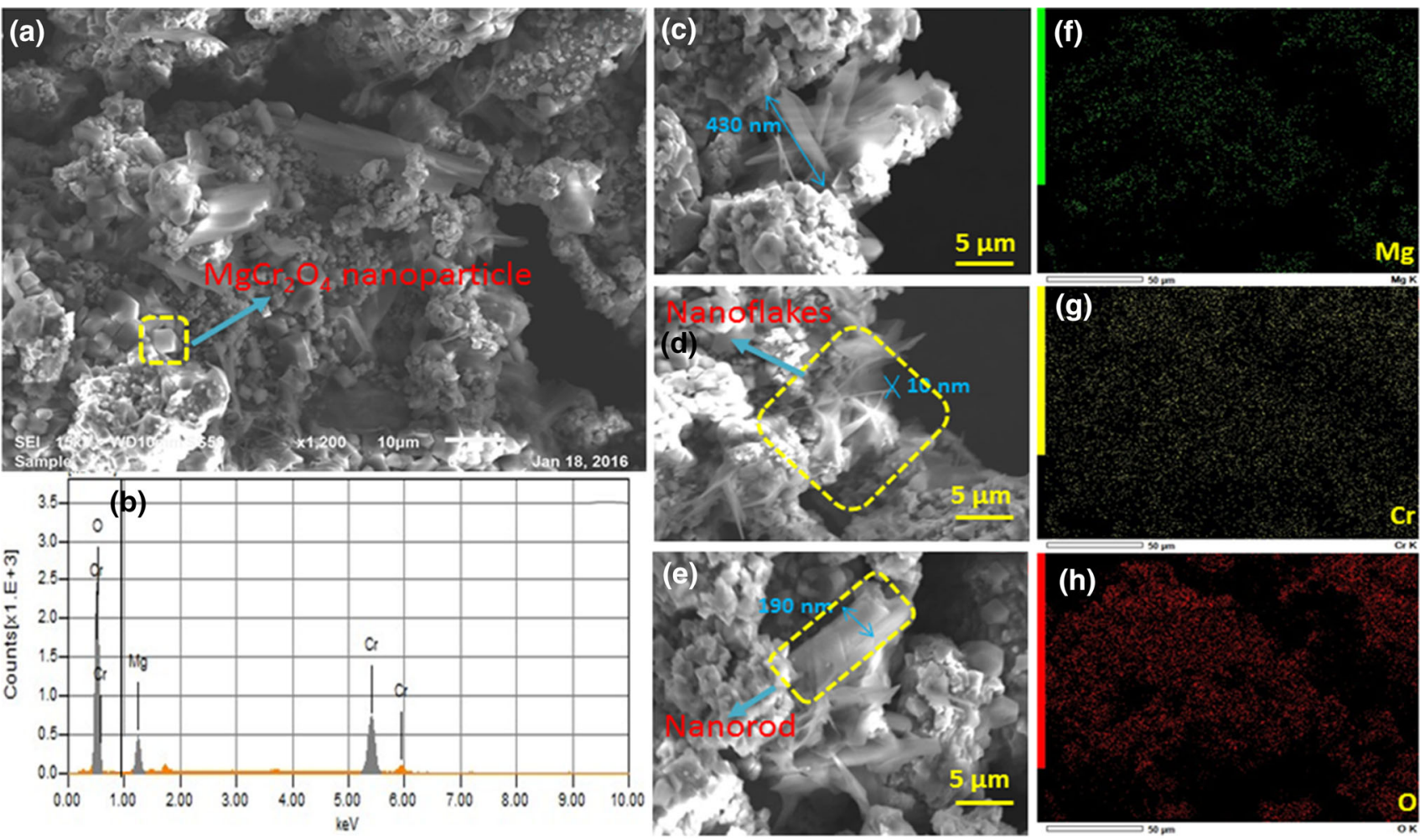

Fig. 9 a SEM image and $\mathbf{c}, \mathbf{d}$, e enlarged images of some parts in $\mathbf{a}, \mathbf{b}$ EDS spectra and elemental mapping of $\mathbf{f} \mathrm{Mg}, \mathbf{g ~ C r}$ and $\mathbf{h ~ O}$ for the $1000{ }^{\circ} \mathrm{C}$ annealed un-templated $\mathrm{MgCr}_{2} \mathrm{O}_{4}$ nanocrystalline powder for $4 \mathrm{~h}$

the elemental mapping of the $\mathrm{Mg}, \mathrm{Cr}$ and $\mathrm{O}$ ions within the $1000{ }^{\circ} \mathrm{C}$ annealed un-templated $\mathrm{MgCr}_{2} \mathrm{O}_{4}$ sample are presented in Fig. 9f, g, h. The results show that the constituent elements are uniformly distributed throughout the sample.

Figure 10a shows an SEM image of the $1000{ }^{\circ} \mathrm{C}$ annealed boiled ESM templated $\mathrm{MgCr}_{2} \mathrm{O}_{4}$ sample. The sample essentially shows the same features as the untemplated sample where aggregates of $\mathrm{MgCr}_{2} \mathrm{O}_{4}$ nanoparticles overlapped with flakes to form mesh like structures; however, the average crystallite size $(t)$ is $25 \%$ less as discussed earlier in "Fresh ESM studies". Figure 10b is an EDS spectrum of the present sample. The analysis of the spectrum revealed the desired nominal chemical composition while the elemental mapping in Fig. 10c, d, e, f indicated uniform distribution of the constituent elements within the $1000{ }^{\circ} \mathrm{C}$ annealed boiled ESM templated $\mathrm{MgCr}_{2} \mathrm{O}_{4}$ sample. The SEM images of the $1000{ }^{\circ} \mathrm{C}$ annealed fresh ESM templated $\mathrm{MgCr}_{2} \mathrm{O}_{4}$ sample are presented in Fig. 11a, c, d, e. The images show morphologies that are quite different than the previous two cases. 3D hierarchical flake-like structure is seen with less pores. The analyses of EDS spectra presented in Fig. 11b gave a composition that correspond to the stoichiometric ratios of $\mathrm{MgCr}_{2} \mathrm{O}_{4}$. The elemental mapping in Fig. 11f, g, $\mathrm{h}$ indicated a uniform distribution of the elements throughout the entire sample.

\section{UV/Vis/NIR spectroscopy studies}

The optical absorption of the $1000{ }^{\circ} \mathrm{C}$ annealed un-templated, boiled ESM templated and fresh ESM templated $\mathrm{MgCr}_{2} \mathrm{O}_{4}$ nanocrystalline powders was investigated by UV/Vis/NIR spectroscopy. Figure 12 shows the optical reflectance spectra of the three samples (un-templated, boiled ESM template, and fresh ESM templated). The spectra suggest an excitonic absorption behavior in the visible range $300-500 \mathrm{~nm}$. The electronic transitions are from the valence band to the conduction band (O-2p level into the $\mathrm{Cr}-3 d$ level). The optical absorbance coefficient $(\alpha)$ of the three samples were calculated from the following equation (Lajunen and Peramaki 2004),

$\alpha d=\ln (1 / T)$,

where $d$ is the path length $(d=1 \mathrm{~cm})$ and $T$ is the transmittance. The transmittance $(T)$ was calculated from the measured absorbance (A) using the relation (Lajunen and Peramaki 2004):

$A=-\log _{10}(T)$.

The insert to Fig. 12 shows plots of the absorption coefficient $(\alpha)$ as a function of wavelength for three samples. It can be seen that the absorption coefficients tend to increase from $300 \mathrm{~nm}$ and reaches a maximum at $374 \mathrm{~nm}$ and then 

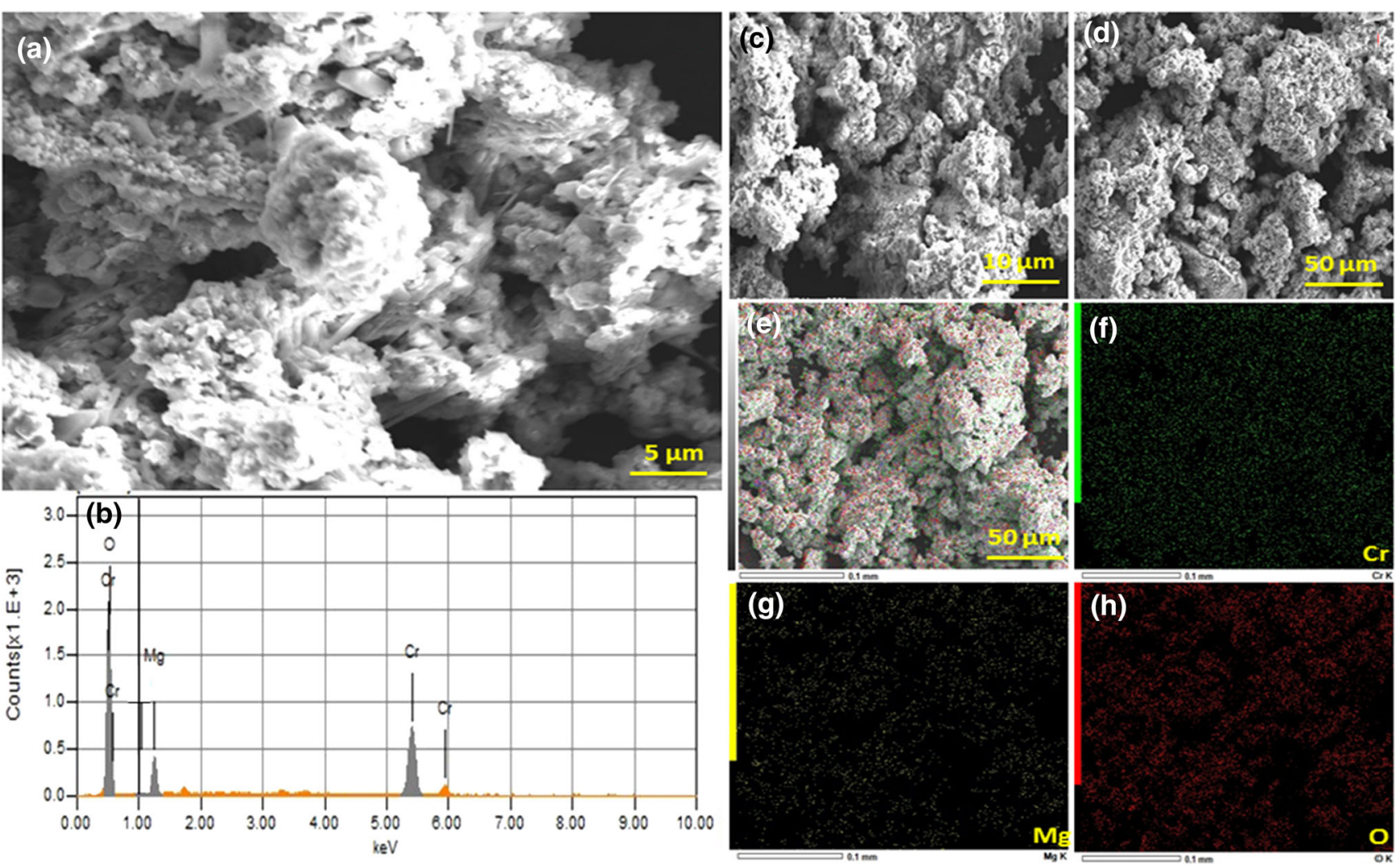

Fig. 10 a, c, d SEM image, b EDS spectra and elemental mapping of $\mathbf{g ~} \mathrm{Mg}, \mathbf{f} \mathrm{Cr}$ and $\mathbf{h} \mathrm{O}$ and $\mathbf{e}$ elemental distribution for the $1000{ }^{\circ} \mathrm{C}$ annealed boiled ESM templated $\mathrm{MgCr}_{2} \mathrm{O}_{4}$ nanocrystalline powder for $4 \mathrm{~h}$

decrease as the wavelength increases. This could be attributed to inelastic scattering of charge carriers by phonons, lattice deformations and internal electric fields within the crystals. Similar behavior was observed for many semiconducting materials (Willardson and Beer 1967).

The optical band gap energies of the $1000{ }^{\circ} \mathrm{C}$ annealed un-templated, boiled ESM templated and fresh ESM templated $\mathrm{MgCr}_{2} \mathrm{O}_{4}$ nanocrystalline powders were calculated from the wavelength value corresponding to the intersection point of the vertical and horizontal part of the spectrum, in accordance with following simple relation (Hamed et al. 2016),

$E_{\mathrm{g}}=1240 / \lambda$

where $E_{\mathrm{g}}$ is the band gap energy $(\mathrm{eV})$ and $\lambda$ is the wavelength in $(\mathrm{nm})$. The calculated values of energy band gap from the above relation correspond to the absorption limit. These values are listed in Table 2 . In order to get more precise values of the optical band gaps, the values of $E_{\mathrm{g}}$ were calculated with the help of the Tauc equation (Hamed et al. 2016),

$\left(\alpha E_{\mathrm{p}}\right)=C\left(E_{\mathrm{p}}-E_{\mathrm{g}}\right)^{m}$,

where $E_{\mathrm{p}}\left(E_{\mathrm{p}}=h v\right)$ is the incident photon energy, $C$ is a constant that depends on the transition probability and $m$ depends on the nature of the optical absorption transition (Hamed et al. 2016). The value of $m$ is $1 / 2$ for direct allowed electronic transition (direct band gap) and 2 for indirect allowed electronic transition (indirect band gap) (Zaki and Sc 2010). For this purpose, $(\alpha h v)^{1 / 2}$ was plotted as a function of photon energy $h v(\mathrm{eV})$ for the indirect gap and $(\alpha h v)^{2}$ against photon energy $h v(\mathrm{eV})$ for the direct gap. Figure 13 is presentation of these plots. The linear intercept at the $h v$ on $x$-axis (shown in Fig. 13) gives the value of the optical bandgap. The estimated optical band gap energies are listed in Table 2. The band gap energies for the three samples are very close, they range from 3.68 to $3.71 \mathrm{eV}$ for the direct band gap and from 3.30 to $3.37 \mathrm{eV}$ for the indirect band gap. These values are not too far from the reported value of $3.4 \mathrm{eV}$ for normal spinel $\mathrm{ZnCr}_{2} \mathrm{O}_{4}$ (Parhia and Manivannan 2008). The $1000{ }^{\circ} \mathrm{C}$ annealed un-templated, boiled ESM templated and fresh ESM templated $\mathrm{MgCr}_{2} \mathrm{O}_{4}$ nanocrystalline powders are sensitive to visible light which could make them suitable photocatalysts (Borse et al. 2011; Parhia and Manivannan 2008).

From the preceding sections, we can say that the use of ESM as a template in the co-precipitation of $\mathrm{MgCr}_{2} \mathrm{O}_{4}$ has an effect on the morphologies and the crystallite grain sizes in the annealed templated $\mathrm{MgCr}_{2} \mathrm{O}_{4}$ nanocrystalline powders. At $1000{ }^{\circ} \mathrm{C}$, the ESM is completely burnt out and none of it is 

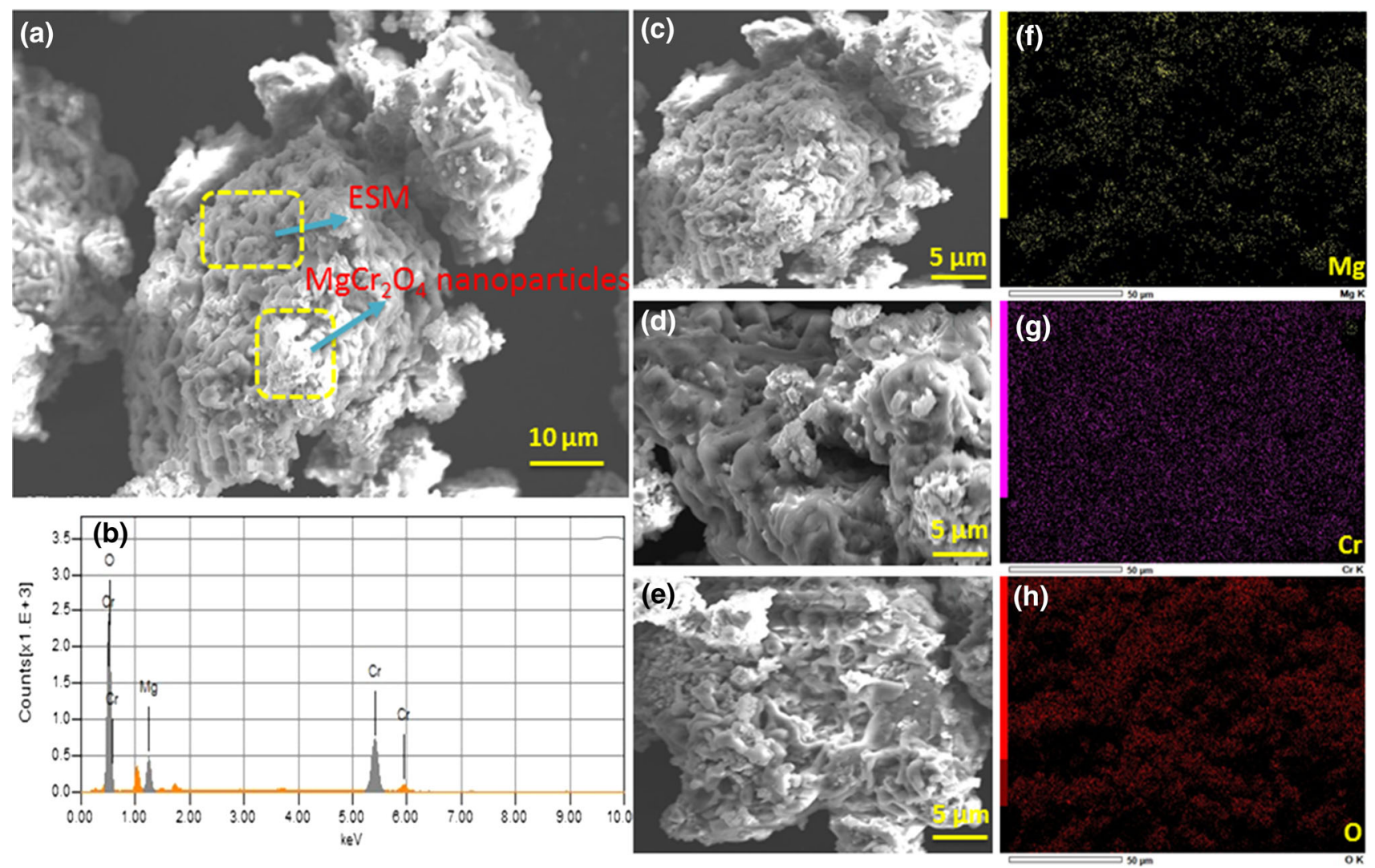

Fig. 11 a SEM image, b EDS spectra and elemental mapping of $\mathbf{c} \mathrm{Mg}, \mathbf{d ~ C r}$ and e $\mathrm{O}$ and e elemental distribution for the $1000{ }^{\circ} \mathrm{C}$ annealed fresh ESM templated $\mathrm{MgCr}_{2} \mathrm{O}_{4}$ nanocrystalline powder for $4 \mathrm{~h}$

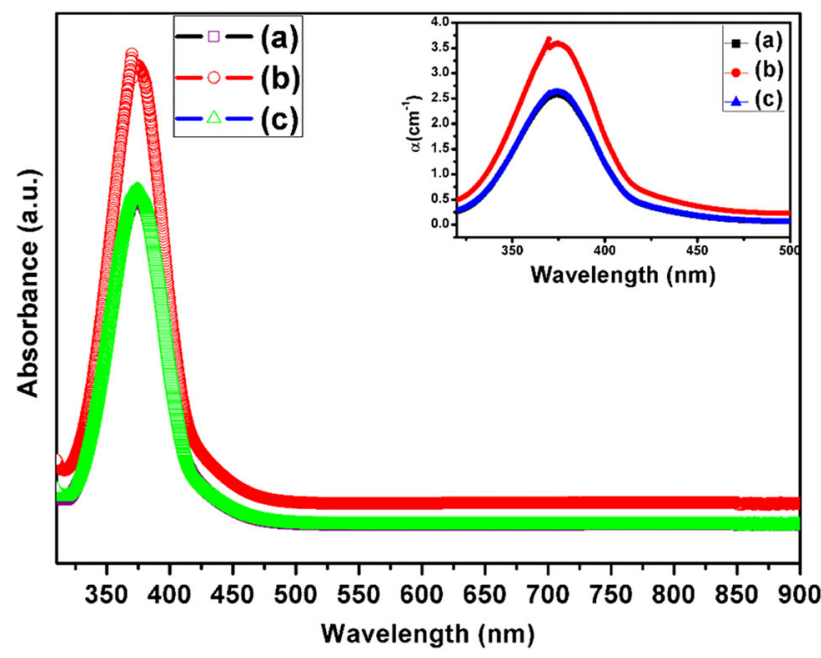

Fig. $12 \mathrm{UV}$ absorbance spectra for of the $1000{ }^{\circ} \mathrm{C}$ annealed $\mathrm{MgCr}_{2-}$ $\mathrm{O}_{4}$ nanocrystalline powder for $4 \mathrm{~h}$ a un-templated, b boiled ESM templated and $\mathbf{c}$ fresh ESM templated

left within the annealed $\mathrm{MgCr}_{2} \mathrm{O}_{4}$ nanocrystalline powders. It seems that the ESM plays a role during the co-precipitation stage and possibly during the annealing stage when the temperature is raised from room temperature to $1000{ }^{\circ} \mathrm{C}$. A simple experiment has confirmed the disappearance of ESM when it was annealed in a matter of $15 \mathrm{~min}$. As far as we know, there are no reports on the optical band gap energies of nanocrystalline $\mathrm{MgCr}_{2} \mathrm{O}_{4}$ except for the report by Tripathi et al. They have reported a value of $1.71 \mathrm{eV}$ for $\mathrm{MgCr}_{2} \mathrm{O}_{4}$ nanoparticles (Tripathi and Nagarajan 2016), we feel that this value is too low in comparison of $3.46 \mathrm{eV}$ reported by Peng et al. for $\mathrm{ZnCr}_{2} \mathrm{O}_{4}$ nanoparticles (Peng and Gao 2008) even though both groups reported similar features in their optical absorption spectra. Both groups reported two extra peaks centered on $440 \mathrm{~nm}$ and $600 \mathrm{~nm}$ in their optical absorption spectra which we do not observe for our nanocrystalline $\mathrm{MgCr}_{2} \mathrm{O}_{4}$ powders. Here we have reported optical band gap energies of nanocrystalline $\mathrm{MgCr}_{2} \mathrm{O}_{4}$ powders. There were small variations in the values of the optical band gap energies between the different samples. There was also a little shading in the color of the three nanocrystalline $\mathrm{MgCr}_{2} \mathrm{O}_{4}$ powders.

\section{Conclusion}

Fresh and boiled eggshell membranes (ESM) were used as a biotemplates during the co-precipitation of pirochromite $\mathrm{MgCr}_{2} \mathrm{O}_{4}$. The un-templated and templated co-precipitated 
Table 2 Optical band gap energies for the $1000{ }^{\circ} \mathrm{C}$ annealed un-templated, boiled ESM templated and fresh $\mathrm{ESM}_{\mathrm{Semplated}} \mathrm{MgCr}_{2} \mathrm{O}_{4}$ nanocrystalline powders for $4 \mathrm{~h}$

\begin{tabular}{llll}
\hline Samples annealed at $1000{ }^{\circ} \mathrm{C}$ for $4 \mathrm{~h}$ & \multicolumn{2}{l}{ Band gap $(\mathrm{eV})$} & \\
\cline { 2 - 4 } & Simple method & Kubelka-Munk function \\
\cline { 2 - 4 } & & Direct & 3.68 \\
Un-templated $\mathrm{MgCr}_{2} \mathrm{O}_{4}$ & 3.41 & 3.71 & 3.30 \\
Boiled ESM templated $\mathrm{MgCr}_{2} \mathrm{O}_{4}$ & 3.53 & 3.69 & 3.32 \\
Fresh ESM templated $\mathrm{MgCr}_{2} \mathrm{O}_{4}$ & 3.43 & & 3.37 \\
\hline
\end{tabular}
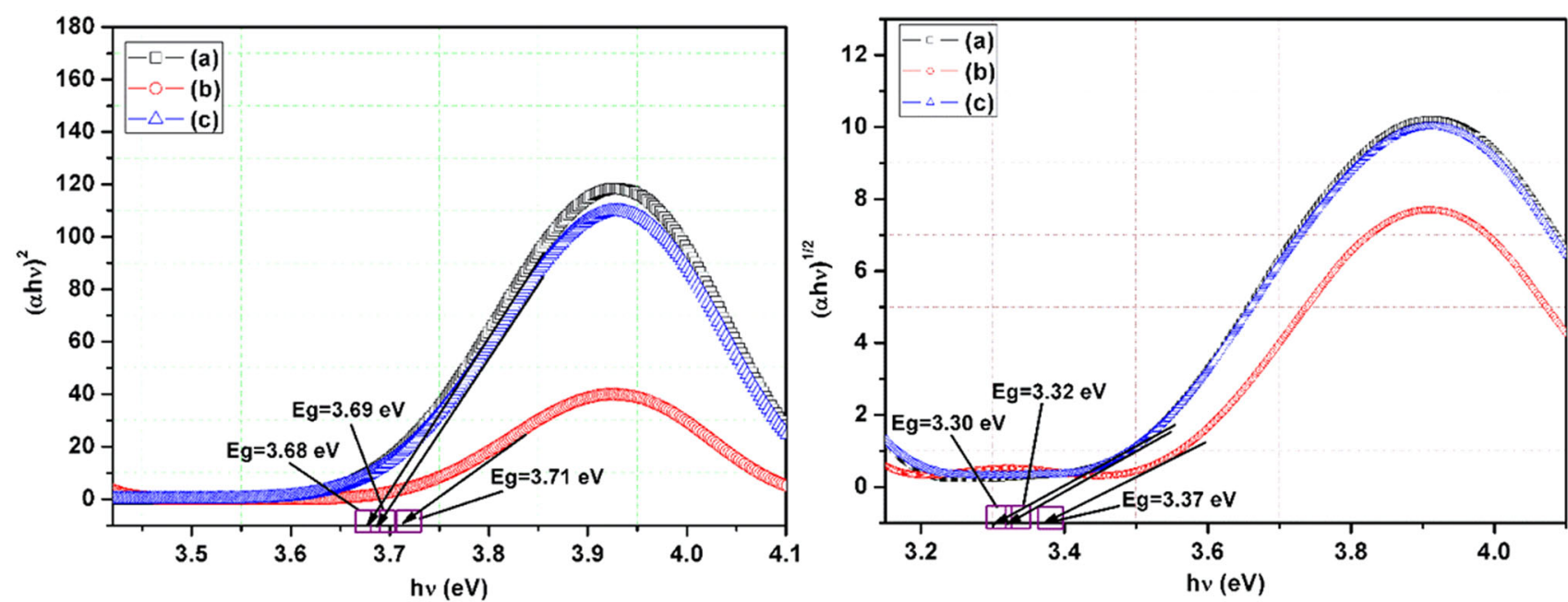

Fig. 13 Tauc plots for direct band gap (left side) and indirect band gap (right side) for the $1000{ }^{\circ} \mathrm{C}$ annealed $\mathrm{MgCr}_{2} \mathrm{O}_{4}$ nanocrystalline powders for $4 \mathrm{~h}$ a un-templated, b boiled ESM templated and $\mathbf{c}$ fresh ESM templated

$\mathrm{MgCr}_{2} \mathrm{O}_{4}$ powders were subjected to heat treatment at $1000{ }^{\circ} \mathrm{C}$ for $4 \mathrm{~h}$ to produce single phase nanocrystalline $\mathrm{MgCr}_{2} \mathrm{O}_{4}$ powders with spinel cubic crystal structure. The un-templated and templated nanocrystalline $\mathrm{MgCr}_{2} \mathrm{O}_{4}$ powders were characterized by XRD, FTIR, SEM, EDS and UV/Vis/NIR spectroscopy. The morphologies and the crystallite grain sizes of the $1000{ }^{\circ} \mathrm{C}$ annealed templated nanocrystalline $\mathrm{MgCr}_{2} \mathrm{O}_{4}$ powders were found to depend on whether the ESM is boiled or fresh. The fresh ESM templated nanocrystalline $\mathrm{MgCr}_{2} \mathrm{O}_{4}$ powders were found to form 3D hierarchical cascading flake-like structure, the boiled ESM templated nanocrystalline $\mathrm{MgCr}_{2} \mathrm{O}_{4}$ formed mesh like structures whereas the un-templated nanocrystalline $\mathrm{MgCr}_{2} \mathrm{O}_{4}$ powders were found to form nano-sized structures with irregular shapes. The un-templated and templated nanocrystalline $\mathrm{MgCr}_{2} \mathrm{O}_{4}$ powders were found to be sensitive to visible light absorption over the range $300-500 \mathrm{~nm}$. This could make them possible photocatalysts over this range. The optical band gap energies were found to vary from 3.68 to $3.71 \mathrm{eV}$ for the direct band gap and from 3.30 to $3.37 \mathrm{eV}$ for the indirect band gap. The concept of using ESM as a template should be extended to other metal oxides nanomaterial.

Acknowledgments This research was supported by the UAEU Program for Advanced Research (UPAR) under grant G00001647, UAE University, Al Ain, United Arab Emirates.

Open Access This article is distributed under the terms of the Creative Commons Attribution 4.0 International License (http:// creativecommons.org/licenses/by/4.0/), which permits unrestricted use, distribution, and reproduction in any medium, provided you give appropriate credit to the original author(s) and the source, provide a link to the Creative Commons license, and indicate if changes were made.

\section{References}

Andrade MJ, Lima MD, Bonadiman R, Bergmann CP (2006a) Nanocrystalline pirochromite spinel through solution combustion synthesis. Mater Res Bull 41:2070-2079

Andrade MJ, Lima MD, Bonadiman R, Bergmann CP (2006b) Nanocrystalline pirochromite spinel through solution combustion synthesis. Mater Res Bull 41:2070-2079 
Arai H, Yamada T, Eguchi K, Seiyama T (1986) Catalytic combustion of methane over various perovskite-type oxides. Appl Catal 26:265-276

Balaz M (2014) Eggshell membrane biomaterial as a platform for applications in materials science. Acta Biomater 10:3827-3843

Benson KF, Ruff KJ, Jensen GS (2012) Effects of natural eggshell membrane (NEM) on cytokine production in cultures of peripheral blood mononuclear cells: increased suppression of tumor necrosis factor-alpha levels after in vitro digestion. J Med Food 15:360-368

Bhosale AG, Chougule BK (2006) X-ray, infrared and magnetic studies of $\mathrm{Al}$-substituted $\mathrm{Ni}$ ferrites. Mater Chem Phys 97:273-276

Borse PH, Jang JS, Lee JS, Khan FN, Ha MG, Kim JP, Bae JS, Jeong ED, Kim HG (2011) Enhanced photocatalytic properties due to electron-rich Ti-ion doping in $\mathrm{ZnFe}_{2} \mathrm{O}_{4}$ under visible light irradiation. J Korean Phys Soc 59:2750-2755

Chen H, Liu J, Cheng X, Peng Y (2012) Adsorption for the removal of malachite green by using eggshell membrane in environment water samples. Adv Mater Res 573-754:63-67

Deng YY, Wang HZ, Zhao HZ (2008) Influence of chrome-bearing sols vacuum impregnation on the properties of magnesia-chrome refractory. Ceram Int 34:573-580

Drazic G, Trontelj M (1989) Preparation and properties of ceramic sensor elements based on $\mathrm{MgCr}_{2} \mathrm{O}_{4}$. Sens Actuators 18:407-414

Finocchio E, Busca G, Lorenzelli V, Willey RJ (1994) FTIR studies on the selective oxidation and combustion of light hydrocarbns at metal oxide surfaces. Propane and propene oxidation on $\mathrm{MgCr}_{2} \mathrm{O}_{4}$. J Chem Soc Faraday Trans 90:3347-3356

Finocchio E, Busca G, Lorenzelli V, Willey RJ (1995a) The activation of hydrocarbon $\mathrm{C}-\mathrm{H}$ bonds over transition metal oxide catalysts: a FTIR study of hydrocarbon catalytic combustion over $\mathrm{MgCr}_{2} \mathrm{O}_{4}$. J Catal 151:204-215

Finocchio E, Busca G, Lorenzelli V, Willey RJ (1995b) The activation of hydrocarbon $\mathrm{C}-\mathrm{H}$ bonds over transition metal oxide catalysts: a FTIR study of hydrocarbon catalytic combustion over $\mathrm{MgCr}_{2} \mathrm{O}_{4}$. J Catal 151:204-215

Ghosh A, Haldar MK, Das SK (2007) Effect of $\mathrm{MgO}$ and $\mathrm{ZrO}_{2}$ additions on the properties of magnesite-chrome composite refractory. Ceram Int 33:821-825

Hamed F, Tholkappiyan R, Vishista K (2016) The effect of induced strains on the optical band gaps in lanthanum doped zinc ferrite nanocrystalline powders. Mod Phys Lett B 30:1650230

Hankare PP, Vader VT, Sankpal UB, Gavali LV, Sasikala R, Mulla IS (2009) Effect of sintering temperature and thermoelectric power studies of the system $\mathrm{MgFe}_{2-\mathrm{x}} \mathrm{Cr}_{\mathrm{x}} \mathrm{O}_{4}$. Solid State Sci 11:2075-2079

Haralkar SJ, Kadam RH, More SS, Shirsath SE, Mane ML, Patil S, Mane DR (2012) Substitutional effect of $\mathrm{Cr}^{3+}$ ions on the properties of $\mathrm{Mg}-\mathrm{Zn}$ ferrite nano particles. Phys B 407:4338-4346

Hashimoto S, Yamagushi A (1995) Growth of $\mathrm{MgCr}_{2} \mathrm{O}_{4}$ whiskers. J Cryst Growth 154:329-333

$\mathrm{He} \mathrm{H}$ (2010) Catalysis and photocatalysis of $\mathrm{MgCr}_{2} \mathrm{O}_{4}$ powder at room temperature. Recent Pat Chem Eng 3:74-77

Hosterman BD, Farley John W, Johnson Allen L (2013) Spectroscopic study of the vibrational modes of magnesium nickel chromite, $\mathrm{Mg}_{\mathrm{x}} \mathrm{Ni}_{1-\mathrm{x}} \mathrm{Cr}_{2} \mathrm{O}_{4}$. J Phys Chem Solids 74:985-990

Ishikawa S, Suyama K, Arihara K, Itoh M (2002) Uptake and recovery of gold ions from electroplating wastes using eggshell membrane. Bioresour Technol 81:201-206

Khalaf KAM, Al-Rawas AD, Widatallah HM, Al-Rashdi KS, Sellai A, Gismelseed AM, Hashim M, Jameel SK, Al-Ruqeishi MS, AlRiyami KO, Shongwe M, Al-Rajhi AH (2016) Influence of $\mathrm{Zn}^{2+}$ ions on the structural and electrical properties of $\mathrm{Mg}_{1-\mathrm{x}} \mathrm{Zn}_{\mathrm{x}-}$ $\mathrm{FeCrO}_{4}$ spinels. J Alloys Compd 657:733-747

Kim BN, Hiraga K, Morita K, Sakka Y (2001) A high-strain-rate superplastic ceramic. Nature 413:288-291

Lajunen LHJ, Peramaki P (2004) Spectrochemical analysis by atomic absorption and emission. Royal Society of Chemistry, Cambridge

Li Z, Zhang L, Amirkhiz BS, Tan X, Xu Z, Wang H, Olsen BC, Holt CMB, Mitlin D (2012) Carbonized chicken eggshell membranes with 3D architectures as high-performance electrode materials for supercapacitors. Adv Energy Mater 2:431-437

Lunge S, Thakre D, Kamble S, Labhsetwar N, Rayalu S (2012) Alumina supported carbon composite material with exceptionally high defluoridation property from eggshell waste. J Hazard Mater 237:161-169

Mann S (2000) The chemistry of form. Angew Chem Int Ed Engl 39:3392-3406

Mann S (2001) Biomineralization. Principles and concepts in bioinorganic materials chemistry. Oxford University Press, Oxford

Morozova LV, Popov VP (2010) Synthesis and investigation of magnesium chromium spinel. Glass Phys Chem 36:86-91

Ning L, Tao L (2011) Adsorption and decoloration of nitroso dye based on eggshell membrane. Adv Mater Res 183-185:963-966

O'Neill HSC, Dollase WA (1994) Crystal structures and cation distributions in simple spinels from powder XRD structural refinements: $\mathrm{MgCr}_{2} \mathrm{O}_{4}, \mathrm{ZnCr}_{2} \mathrm{O}_{4}, \mathrm{Fe}_{3} \mathrm{O}_{4}$ and the temperature dependence of the cation distribution in $\mathrm{ZnAl}_{2} \mathrm{O}_{4}$. Phys Chem Miner 20:541-555

Oliveira DA, Benelli P, Amante ER (2013) A literature review on adding value to solid residues: egg shells. J Clean Prod 46:42-47

Parhia P, Manivannan V (2008) Microwave metathetic approach for the synthesis and characterization of $\mathrm{ZnCr}_{2} \mathrm{O}_{4}$. J Eur Ceram Soc 28:1665-1670

Peng C, Gao L (2008) Optical and photocatalytic properties of spinel $\mathrm{ZnCr}_{2} \mathrm{O}_{4}$ nanoparticles synthesized by a hydrothermal route. J Am Ceram Soc 91:2388-2390

Rida K, Benabbas A, Bouremmad F, Pena MA, Martinez-Arias A (2010) Influence of the synthesis method on structural properties and catalytic activity for oxidation of $\mathrm{CO}$ and $\mathrm{C}_{3} \mathrm{H}_{6}$ of pirochromite $\mathrm{MgCr}_{2} \mathrm{O}_{4}$. Appl Catal A 375:101-106

Ruff KJ, DeVore DP, Leu MD, Robinson MA (2009) Eggshell membrane: a possible new natural therapeutic for joint and connective tissue disorders. Results from two open-label human clinical studies. Clin Interv Aging 4:235-240

Schoonman J, Dekker JP, Broers JW (1991) Electrochemical vapor deposition of stabilized zirconia and interconnection materials for solid oxide fuel cells. Solid State Ion 46:299

Stefanescua M, Barbu M, Vlase T, Barvinschi P, Barbu-Tudoran L, Stoia M (2011) Novel low temperature synthesis method for nanocrystalline zinc and magnesium chromites. Thermochim Acta 526:130-136

Tripathi VK, Nagarajan R (2016) Rapid synthesis of mesoporous, nano-sized $\mathrm{MgCr}_{2} \mathrm{O}_{4}$ and its catalytic properties. J Am Ceram Soc 99:814-818

Wang WD, Chen B, Huang YM, Cao J (2010) Evaluation of eggshell membrane-based bio-adsorbent for solid-phase extraction of linear alkylbenzene sulfonates coupled with high-performance liquid chromatography. J Chromatogr A 1217:5659-5664

White WB, De Angelis BA (1967) Interpretation of the vibrational spectra of spinels. Spectrochim Acta A 23:985-995

Willardson RK, Beer AC (1967) Semiconductor and semimetals: optical properties of III-V compounds. Academic Press, New York 
Zaki SM, Sc M (2010) Thesis in physics, Faculty of science. Tanta University, Egypt

Zhang HM, Teraoka Y, Yamazoe N (1987) Preparation of perovskitetype oxides with large surface area by citrate process. Chem Lett $16: 665-668$
Zheng BZ, Xie SP, Qian L, Yuan HY, Xiao D, Choi MMF (2011) Gold nanoparticles coated eggshell membrane with immobilized glucose oxidase for fabrication of glucose biosensor. Sens Actuators B Chem 152:49-55 